\title{
A Study On Buyer Manners Towards Banking Services With Special Reference To Public Sector Banks In Adilabad District
}

\author{
D.Sukhaprada Devi ${ }^{1}$.Dr.Badiuddin Ahmed ${ }^{2}$, Ramakanth $^{3}$ \\ Lecturer in commerce,Adilabad
}

\begin{abstract}
In the present paper discuss buyer manners towards banking services by special position to public region in Adlibbed district. The position of business banks is mainly essential in The employment of supply. Better allocation. The growth method of below developed countries. By giving striking economy scheme. And ensuring the security of deposits marketable banks support motivation, To accumulate among the people in rural/urban areas. They make possible in the bearing of trade still saving in to successful one. Business banks progress the allocation of resources by lending money toward partiality sectors of the market. The community division banks in India operate In a highly competitive environment with competition from non banking financial institution. Foreign banks intensifying walk business for Indian banks in respect of deposits can no longer be expected. In arrange to carry on in these days of violent opposition community division banks have to apply .promotion move toward creation separation is often employed as a major method to survive in a vigorous market. Each bank follow different practice it is very difficult to pursue the operate. Even through the consumer is well educated some time high contact banking services be uncertain the customer for the contract. For the helpful banking business the banks .
\end{abstract}

Keywords : customer behavior, commercial bank, mobilization, better allocation, good communication, Soft skill must need.

\section{Introduction}

Buyer manners is the study of those, groups, or organizations and the processes they use to choose, safe, use, and organize of goods, services, experiences, or dreams to convince needs and the impacts that these process contain on the buyer and culture. It blends essentials from psychology, sociology, social anthropology, marketing and Economics. It attempts to know the executive processes of buyers, both alone and in groups such as how emotions affect buying manners. It studies characteristics of individual consumers such as demographics or personality ${ }^{[2]}$ and behavioural variables in an attempt to understand people's wants. It also tries to assess influences on the consumer from groups such as family, friends, sports, reference groups, and society in general. The sellers market has disappeared and buyers market has come up.

It is broadly the study of individuals, or organizations and the processes consumers use to search, select, use and dispose of products, services, experience, or ideas to satisfy needs and its impact on the consumer and society.A bank is a financial institution that provides banking and other financial services to their customers. A bank is generally understood as an institution which provides fundamental banking services such as accepting deposits and providing loans. There are also nonbanking institutions that provide certain banking services without meeting the legal definition of a bank. Banks are a subset of the financial services industry. A banking system also referred as a system provided by the bank which offers cash management services for customers, reporting the transactions of their accounts and portfolios, through out the day. The banking system in India, should not only be disturb free but it should be able to meet the new challenges posed by the technology and any other external and internal factors.

The Banking sector offers several conveniences and opportunities to their customers. All the banks safeguards the money and proceeds and provide loans, credit, and payment services, such as examination financial records, money orders, and cashier's cheques. The banks in addition offer speculation and assurance goods. As a variety of models for teamwork and addition between finance industries have emerge, some of the traditional distinctions between banks, insurance companies, and securities firms have diminished. In spite of these changes, banks continue to maintain and perform their primary role-accepting deposits and lending funds from these deposits.

buyer are now challenging numerous channel through which they can interact with their providers including to face to face call, telephone, Websites e-mail mobile device etc. Which has required the banking subdivision to discover new allocation channel, so that normal buyer which have additional in order about numerous banking goods than even before. This is expected not only to in attendance the buyer from pleasing their business away but also to ensure that they are offered the product and services that are most fitting and the majority possible to effect in new returns for the bank. In this process of contract is to be accepted out competently it is absolutely essential that the banks be involved. Indian banking has aided the economic 
development in an effective way during the post independence period. The banking sector has shown remarkable responsiveness to the needs of the intended market. It has brought about a considerable progress in its efforts at deposits recruitment It has taken a number of determine in the current past to increase speed the rate of growth of deposits. To achieve this wants commercial banks opened a Number of branches in Urban , Semi urban ,Rural areas and also Introduced a number of attractive schemes Free services to customer attract more customer.

\section{Review Of Literature}

1. Marla Royne Stafford [1996] "Demographic discriminators of service quality in the banking industry",

2. Mathew Joseph, Cindy McClure, Beatriz Joseph [1999]"Service quality in the banking sector: the impact of technology on service delivery",

3. Robert Johnston [1997] "Identifying the critical determinants of service quality in retail banking: importance and effect",

4. DuBrin A.J. p[2007], "Leadership: Research Findings, Practice and Skills",

5. 5.Houghton Mifflin Company. Boston, N.Y. Karin Newman, Alan Cowling [1996] "Service quality in retail banking: the experience of two British clearing banks

6. Peter Kangis, Vassiliki Passa [2002] "Awareness of service charges and its influence on customer expectations and perceptions of quality in banking",

7. Albert Caruana [2002] "Service loyalty: The effects of service quality and the mediating role of customer satisfaction" and "Customer perceptions of service quality in the banking sector of a developing economy: a critical analysis",

\section{Statement Of The Problems}

Aadilabad Town there are more public sector and private sector banks were functioning . the researcher investigator have 120 choosen this topic to study about banking services provided by public subdivision banks there is a problem of

1. Abnormal delays in receiving and Marketing expense ,

2. To examine the problems involved in banking call,

3. To propose apposite corrective compute to get better their banking services.

4. the present customer services systems lacks motivation and initiatives, those adversely affect the customer service.

5. To examine the current banking skill and its repercussions on the excellence of buyer air force.

\section{Methodolog}

In this paper on adilabad district study covers both primary and secondary data. The primary data collected by interview method through the well structured questionnaire. For this research five public sector banks were selected in adilabad district mainly focus State bank of India, Andhra bank, union bank, Indian bank state bank of Hyderabad among these branch's .The researcher has chosen five banks from adilabad district . From the five public sector banks each bank 120( all five banks ) customers were selected by using random sampling method. The secondary data was collected from the published records, books journals encyclopedias, government surveys and web portals. The collected data have been processed and analyzed with the help of the following, SPSS tools used to test the hypotheses 1) $X_{2}$ test 2) $t$ test and F test 3) Standard devision,4) Arithmetic man were used.

\section{Educational Qualification}

Education in the major sense is any act or knowledge that has a determining outcome on the intelligence, quality or physical ability of an person. In its technical sense, education is the process by which society intentionally transmits its accumulated knowledge, skill and values form one generation to another.

Table1

\begin{tabular}{|l|l|l|l|}
\hline S.No & Educational Qualification & No of Respondents & Percentage \\
\hline 1. & Illiterate & 10 & 10 \\
\hline 2. & Up to 10th & 35 & 35 \\
\hline 3. & 11 th -12th and Diploma & 25 & 25 \\
\hline 4. & Under graduate & 20 & 20 \\
\hline 5. & Post graduate & 30 & 30 \\
\hline Total & 100 & 120 & 120 \\
\hline
\end{tabular}

Source: Primary data 
The above table reveals that 10 percent of respondents were comes under the category of illiterates and 24 percent of the respondents were studied up to 10th standard. The above table exhibit 35 percent of respondents were under graduates and also 20 percent of respondent were post graduate. From this study it is clear that the bank has focus all the category of customer.

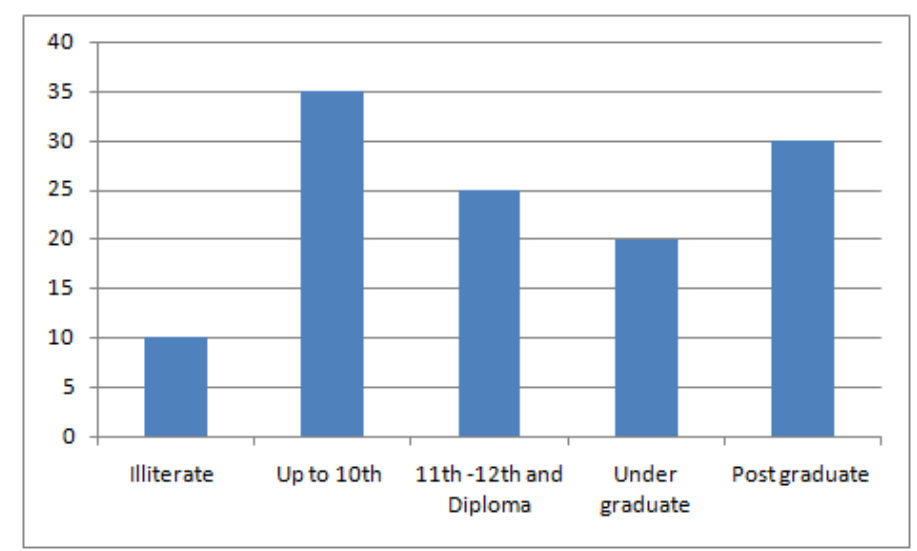

Educational qualification

Table 2: Occupation Of The Respondents

\begin{tabular}{|l|l|l|}
\hline S.No & occupation & No of Respondents \\
\hline 1. & service & 12 \\
\hline 2. & Profession & 28 \\
\hline 3. & Business & 14 \\
\hline 4. & Pensioners & 23 \\
\hline 5. & Agriculture and other & 43 \\
\hline Total & & 120 \\
\hline
\end{tabular}

Source : primary data

commencing the above table indicates that 12 percent of the respondents were comes under services and common of the respondents that is 28 percent of respondents professional and 14 per cent of respondents business it is clearly understood that the majority of the respondents working under some organization it shows their employability it will helps to growth of the nation. Only 23 percent of respondents were pensioner and also agriculturist because they are not willing to go bank

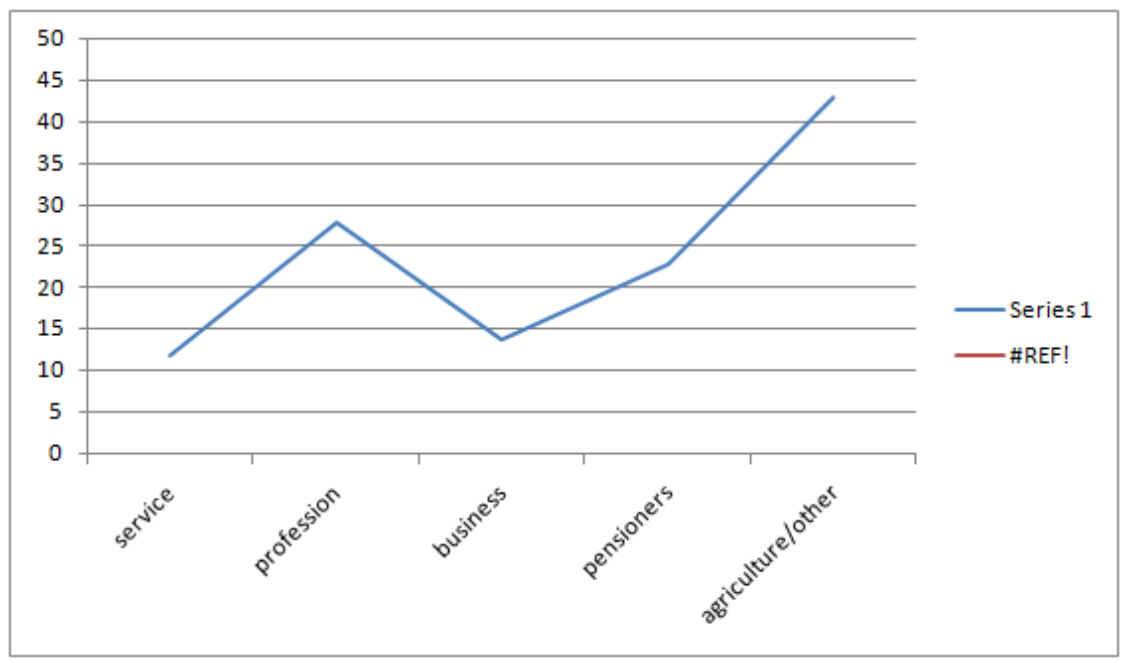

\section{Monthly Income}

Income is the expenditure and investments chance gained by an article within a particular time frame, which is generally expressed in monetary terms. However, for households and individuals, "income is the sum of all the wages, salaries, profits, interests' payments, rents and other forms of salary acknowledged in a given period of time". Simply we can say income is the reward of four facto of manufacture that is land, labour, capital and organization. The following table explains the monthly income of respondents. 
Table -3

\begin{tabular}{|l|l|l|}
\hline S.No & Monthly income (income in Rs) & No.of Respondings \\
\hline 1 & Below 5000 & $\mathbf{1 0}$ \\
\hline 2 & $5000-10000$ & $\mathbf{2 4}$ \\
\hline 3 & $10000-15000$ & $\mathbf{2 6}$ \\
\hline 4 & $15000-20000$ & $\mathbf{3 6}$ \\
\hline 5 & Above 20000 & $\mathbf{2 4}$ \\
\hline & total & $\mathbf{1 2 0}$ \\
\hline
\end{tabular}

Source: Primary data

The above table clearly shows that 10percent of respondents earning below 5000 and 29 per cent of respondents were earning 5000-10000 then 24 and 26 percent of the respondents getting income 10000-15000 because they are working in prepared sector in adilabad district.. The above table reveals 24 percent of respondents earning income above 20000 they are business people. So income is very important factor to resolve the location of every person without income no cannot survive their life.

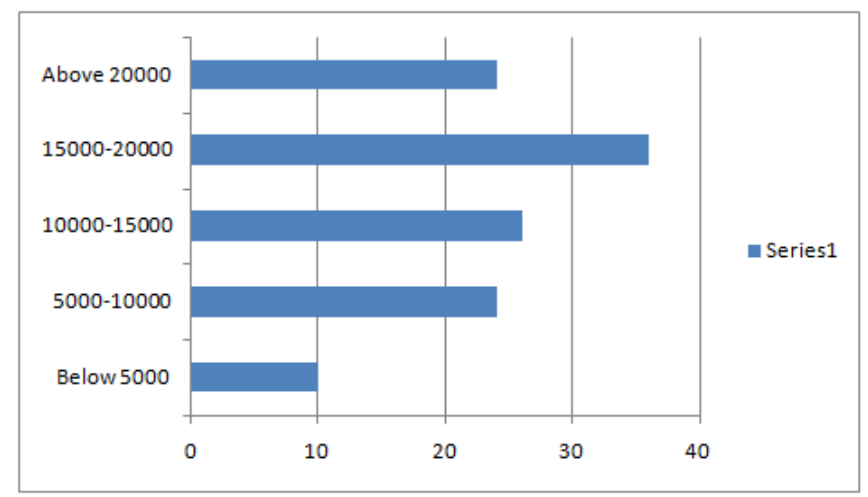

\section{Technology In Banking Services}

Bank should play a very important role servicing different kind of knowledge this resolve helps to the bank to avoid complexity. The following table explain about the banking technology offered by the bank.

Source: Primary data

\begin{tabular}{|l|l|l|}
\hline S.No & Banking technique & No.of Respondings \\
\hline 1 & ATM & $\mathbf{2 4}$ \\
\hline 2 & Tele banking & $\mathbf{2 0}$ \\
\hline 3 & Mobile banking & $\mathbf{2 6}$ \\
\hline 4 & Electronic fund transfer & $\mathbf{2 4}$ \\
\hline 5 & Internet banking & $\mathbf{3 6}$ \\
\hline & total & $\mathbf{1 2 0}$ \\
\hline
\end{tabular}

The above table depict that the majority of the respondents were using ATM services because ATM is one of the most popularized services given by bank. The customer with draw money any part in the world so the percentage is very high. Only 24 per cent of respondents were using telephone banking. There are large number of respondents were using mobile banking now a days this banking popularized from the business people. Very less number of respondents were using other banking technique because of complex procedure they are not using internet banking.

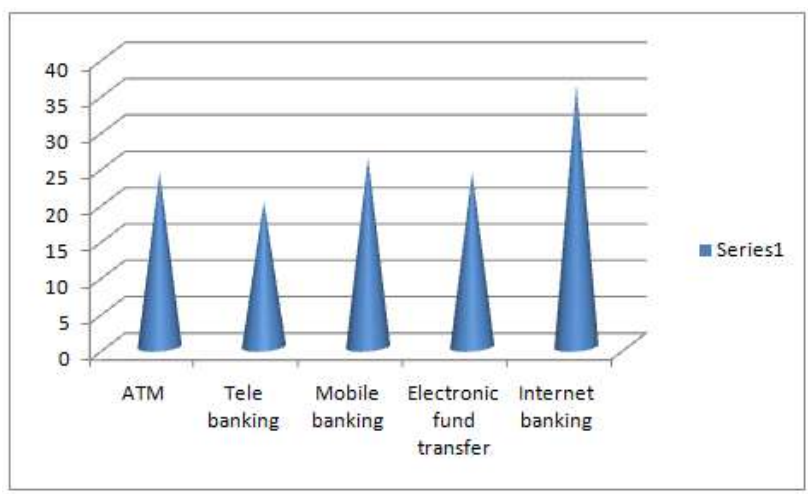




\section{Regularly Using Services}

Bank supply number of services to the buyer but the buyer were using limited services because lake of time, composite procedure and technical problem in the processor. This is may make problem to the buyer. The following table explains the buyer regularly using services.

Source: Primary data

\begin{tabular}{|l|l|l|}
\hline S.No & Particulars & No.of Respondings \\
\hline 1 & Deposit Cash & $\mathbf{1 0}$ \\
\hline 2 & With draw money & $\mathbf{2 4}$ \\
\hline 3 & Demand draft & $\mathbf{2 6}$ \\
\hline 4 & Fund transfer & $\mathbf{3 6}$ \\
\hline 5 & Collection of cheque & $\mathbf{2 4}$ \\
\hline & total & $\mathbf{1 2 0}$ \\
\hline
\end{tabular}

The above table explains that 10 percent of respondents deposit their cash in a bank it shows that deposit cash in a bank one way it helps to the bank to mobilize fund and another way the customer with draw money in a bank are ATM during the need of cash.The study indicates that 24 per cent of respondents with draw money from the bank and 26 percent of respondents demand draft for the different purposes.

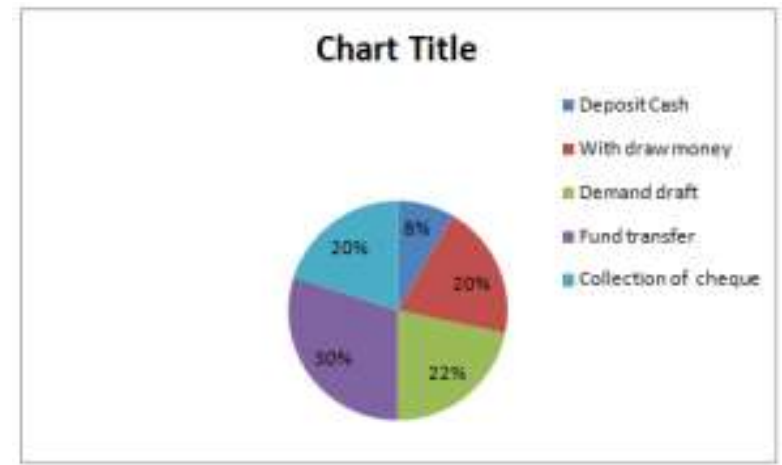

\section{Important Reason To Contact The Branch}

For the many motive the buyer visit to the bank. The following table shows the most important reason buyer conduct the division.

Source :primary data

\begin{tabular}{|l|l|l|}
\hline S.No & Important reason & No.of Respondings \\
\hline 1 & Loan enquiry & $\mathbf{1 0}$ \\
\hline 2 & complaints & $\mathbf{2 4}$ \\
\hline 3 & Confirming fund transfer & $\mathbf{2 6}$ \\
\hline 4 & Inquires about my credit card & $\mathbf{3 6}$ \\
\hline 5 & Other reasons & $\mathbf{2 4}$ \\
\hline & total & $\mathbf{1 2 0}$ \\
\hline
\end{tabular}

Surrounded by the 120 respondent 10 percent 10 per cent of them to contact the branch to conforming their funds it is shown in the above table. Some of the respondents to visit the branch enquiry about the loan, complaint inquiries about their credit card. It significant to note that 24 percent of the respondents conducting branch some other reason.

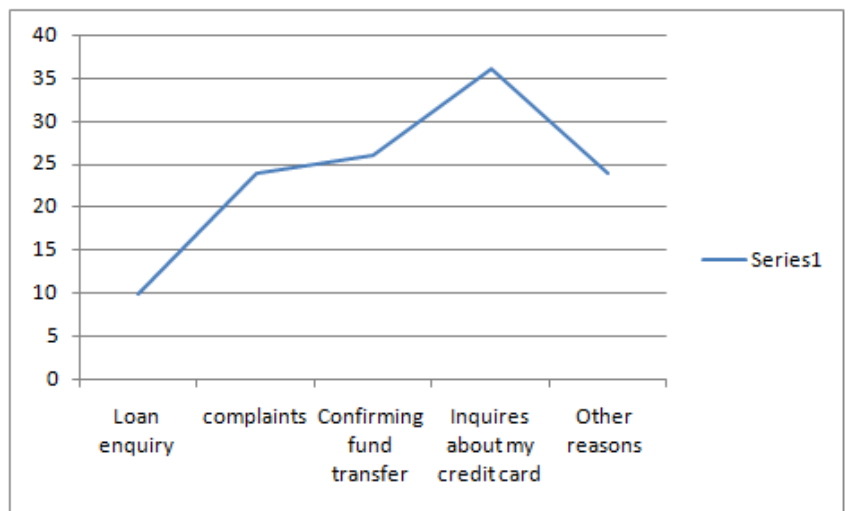




\section{Customer Difficulties In Bank Transaction}

Customers faced many difficulties during the financial transactions. The subsequent table explains particulars about the major difficulties faced by the customer.

\begin{tabular}{|l|l|l|}
\hline S.No & Customer difficulties in bank transaction & No.of Respondings \\
\hline 1 & Delay in banking function & $\mathbf{1 0}$ \\
\hline 2 & Problems of ATM & $\mathbf{2 4}$ \\
\hline 3 & Service charge & $\mathbf{2 6}$ \\
\hline 4 & Improper behavior of employes & $\mathbf{3 6}$ \\
\hline & total & $\mathbf{2 4}$ \\
\hline
\end{tabular}

10 of the respondents be face in delay in banking function it is exposed in the above table . It is clearly indicate that other services like problem of ATM, service charge, Service charge and improper behavior of employees is not giving more difficulties to the customer.

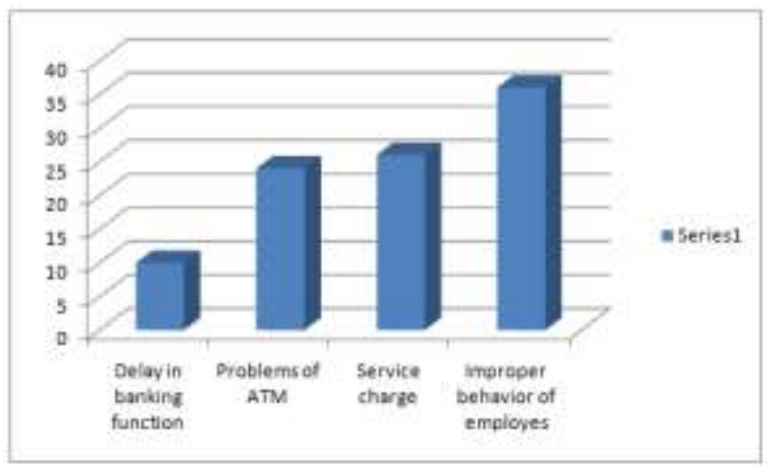

\section{Quality Of Service In Bank.}

Quality itself has been defined as fundamentally relational quality is the ongoing process of building and sustaining relationship by assessing, anticipating and fulfilling stated and implied needs. This following table has shown the quality of services in bank.

\begin{tabular}{|l|l|l|}
\hline S.No & Quality of service & No.of Respondings \\
\hline 1 & Excellent & $\mathbf{2 0}$ \\
\hline 2 & Very good & $\mathbf{3 5}$ \\
\hline 3 & Good & $\mathbf{2 5}$ \\
\hline 4 & Average & $\mathbf{1 5}$ \\
\hline 5 & poor & $\mathbf{1 5}$ \\
\hline & total & $\mathbf{1 2 0}$ \\
\hline
\end{tabular}

It is clear that from the above table the majority of the respondents were told the banking services are excellent. The table exhibit that the 20 percent respondents were told the banking activities is very good. Most of them accepted the banking services is good.

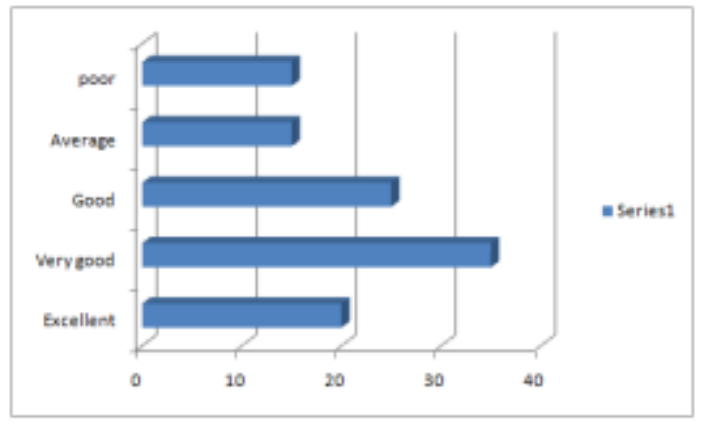

\section{Findings}

Study of researcher could arrive at the following findings. These findings will help the researcher to give proper suggestion to the bank for improved performance.

$>$ the Survey the buyer are well educated in adilabad distrct city majority of the people well educated and also buyer belongs to profession and business people. 
$>$ It is clearly indicate that other services like problem of ATM, Service charge, Service charge and Improper behavior of employees is not giving more difficulties to the buyer.

$>$ It is important to note that among the 120 respondents 60 of them were said not providing quick services. It shows the bank inabilities to satisfy the buyer expectation. In adilabad district.

$>$ The bank should provide good environment in order to face huge number of customer like head branch all sub branch need same facility.

$>$ - If the bank introduced new bank scheme the notice board should display in front of the bank.

\section{Conclusion}

1. The banking sector has changes the new economic policy based on privatization, globalization and liberalizations adopted by government of India.

2. Today the customer services preference keep on changing at a rapid speed and their demands.

3. The aim of the bankers is to make the customers comfortably and happy to achieve their targets. To achieve the highly challenging task of customers satisfaction bankers turning to technology for help.

4. Bankers are not only satisfying the buyer but should also trigger to attitude of the customers towards the bank. Each bank follow different procedure it is very difficult to follow the customers.

5. Even though the buyer is well educated some time high technology banking services hesitate the customer for the transaction. For the effective banking transaction the banks should have good communication, soft skill must need. Universal banking procedure can help the customer for the better transaction.

\section{Reference}

[1]. A.Ananth arul Raj. A (2011), A study on banking quality in Nagapattinam district, Tamilnadu Indian Journal of Marketing Vol.41,P4.

[2]. Oommen A. Ninan July, 10(2011), Major role of technology in financial inclusion, The Hindu.

[3]. Pranapmukarji (2011) Catalyst for growth_Financial Inclusion, Financial services, The analyst p-20.

[4]. Subodh kumar and RPS Rawat (2011) Treat customer fairly and BCSBI Southern economistVol-49 pp49.

[5]. Saima Rizvi etal (2011) Determinants of dividend payout ratios a study of the Indian banking sector Indian journal of finance p-24.

[6]. Ghosh and kalishB1 (2011),"Impact of services quality on customer satisfaction,loyality and commitment in the banking sector, "Indian journal of marketing, vol.40 no.5 p.23.

[7]. Mshra anubhv anand (2010),'Factors affecting customers satisfaction and their Relative Importance in retail banking sector an empirical study ,"The IUP Journal of management research,vol.ix,No.3,p.7

[8]. Kumar M and Rajesh R (2009),"whether today's customer are satisfied?", India journal of marketing,vol.xxxix,no.9,p.46.

[9]. Shiralsheeti As etal (2011) Banking services and customer satisfaction: A study on banks Belgum District, Karnataka, "The IUP journal of Managerial Economics, Vol.ix.No.2,pp.57-58.

[10]. Balakrishnnan R Gayathri (2010), "Customer Awarness about the banking services; A study,"Southern Economist, Vol.49,No.15,p.2.

Walfried M. Lassar, Chris Manolis, Robert D. Winsor (2000), "Service quality perspectives and satisfaction in private banking", Journal of Services Marketing, Vol. 14, Issue 3. Marla Royne Stafford (1996), "Demographic discriminators of service quality in the banking industry", Journal of Services Marking, Vol. 10, Issue 4. Mathew Joseph, Cindy McClure, Beatriz Joseph (1999), "Service quality in the banking sector: the impact of technology on service delivery", International Journal of Bank Marketing, Vol. 17, Issue 4. Robert Johnston (1997), "Identifying the critical determinants of service quality in retail banking: importance and effect", International Journal of Bank Marketing, Vol. 15, Issue 4. Roger Best (2009), "Market-Based Management: Strategies for growing customer value and profitability", 5th edition, Pearson, Prentice Hall. Mosad Zineldin (2002), "Managing in the @ age: Banking service quality and strategic positioning" Measuring Business Excellence, Vol. 6, Issue 4. Spiros P. Gounaris, Vlassis Stathakopoulos, Antreas D. Athanassopolos (2003), "Antecedentss to perceived service quality: an exploratory study in the banking industry", International Journal of Bank Marketing, Vol. 21, Issue 4. Madhukar G. Angur, Rajan Nataraajan, John S. Jahera Jr. (1999), "Service quality in the banking industry: an assessment in a developing economy", International Journal of Bank Marketing, Vol. 17, Issue 3. DuBrin A.J. (2007), "Leadership: Research Findings, Practice and Skills", Houghton Mifflin Company. Boston, N.Y. Karin Newman, Alan Cowling (1996), "Service quality in retail banking: the experience of two British clearing banks", International Journal of Bank Marketing, Vol. 14, Issue 6. Kamilia Bahia, Jacques Nantel (2000), "A reliable and valid measurement scale for the perceived service quality of banks", International Journal of Bank Marketing, Vol. 8, Issue 2. Faye X. Zhu, Walter Wymer, Injazz Chen (2002), "IT-based service quality in consumer banking", International Journal of Service Industry Management, Vol. 13, Issue 1. Peter Kangis, Vassiliki Passa (2002), "Awareness of service charges and its influence on customer expectations and perceptions of quality in banking", Journal of Services Marketing, Vol. 11, Issue 2. 40 Albert Caruana (2002), "Service loyalty: The effects of service quality and the mediating role of customer satisfaction", European Journal of Marketing, Vol. 36, Issue 7/8. G.S. Sureshchandar, Chandrasekharan Rajendran, R.N. Anantharaman (2003), "Customer perceptions of service quality in the banking sector of a developing economy: a critical analysis", International Journal of Bank Marketing, Vol. 21, Issue 5. Daniel Nukpezah, Cephas Nyumuyo (2009), "What drives customer loyalty? Analysis of perspectives from retail customers in Ghana's banking industry". Peter Kangis, Vassilis Voukelatos (1997), "Private and public banks: a comparison of customer expectations and perceptions", International Journal of Bank Marketing, Vol. 15, Issue 7. G.S. Sureshchandar, Chandrasekharan Rajendran, R.N. Anantharaman, T.J. Kamalanabhan (2002), "Management's perception of total quality in the banking sector of a developing economy - a critical analysis", International Journal of Bank Marketing, Vol. 20, Issue 4. Ahmad Jamal, Kamal Naser (2002), “Customer satisfaction 